\title{
There is no Best Teaching Method Based on ELT Methods Innovation Change
}

\author{
Xiaoning He \\ The Education University of Hong Kong \\ Claire_eye@yeah.net
}

\begin{abstract}
Teaching methods has been developed over years and critics want to figure out one of the best. This paper uses lots of examples to illustrate that there is no one teaching method can adapt to all situations and every teaching method has its own value. the most important thing should be combining these methods together to get better good results.
\end{abstract}

Keywords: Contemporary language learning, Teacher's belief, Teaching context, Pedagogical implication.

\section{Introduction}

Teaching methods are one of the most vital components of contemporary language learning. The traditional perspective of the development of language teaching methods over time is that "there has been a series of language teaching methods over the years, each being succeeded by a better one until we reach the present" (Pennycook, 1989: 597). From this view, there have been so many language teaching methods "in response to changing geopolitical circumstances and social attitudes and values, as well as to shifts of fashion in linguistics" (Cook, 2003: 30). It's hard to say that one method is inherently superior to another because each has strengths and weaknesses, and the nature of a teacher's goals will determine which is best for teaching. When discussing methods, teachers always believe that there is no such a best teaching method to adapt for all teaching circumstances. Indeed, comparing methods to find out which is 'best' is meaningless, as teaching contexts always change. Using different teaching methods of complementation is the aim of the development of methods. This essay will justify that there is no best teaching method. Furthermore, three supporting reasons will be explained, including (1) different methods have their own value; (2) how to implement teaching methodologies in different circumstance depends on teachers' beliefs and teaching contexts; (3) methods can be combined.

\section{Different Methods Have Their Own Value}

One great method has its own function in one aspect, but it may be challenged by another one in different aspects. From the late nineteenth century to the present day, the teaching methods have been updated constantly in order to meet the increasing demand of language learning. As stated by Jacobs and Farrell (2003:5), "the call for change is almost constant in education", and the new method always complements and updates the drawbacks of the old method. There is no denying that the grammar-translation method provides structure and security to lower-proficiency learners, as it can view the study of a language as the memorization of rules to be able to manipulate its morphological and syntactical system (Benati, 2018). However, this method is still challenged by the developed methods such as the direct method which responds to shortcomings in it.
As mentioned by Crookes (2009), for example, the direct method was highlighted, while grammar-translation method was gradually abandoned at the end of the nineteenth century in Europe. This is because grammar-translation method emphasizes heavily on grammar rules and memorization, so that it lacks cohesion with language facts -- communication. In this case, the direct method has solved this problem by using the target language as the medium of instruction, which enables students to think in the target language and communicate.

On the other hand, the development of teaching methods conforms to the changing academic fashions, societal and scientific thinking or political circumstances. As argued by Hall, "the late nineteenth century was an era in which the development of international business and travel required language learners to be able to use and communicate in the L2, an aim that Grammar-translation method did not appear to fulfill" (Hall, 2018). Therefore, the direct method plays a significant role in filling the gap left by grammar-translation method. Teaching methods need to meet social needs, which can be taken as the most useful way to help people master foreign languages so as to improve scientific, cultural, political development.

However, the grammar-translation method is still used by many ELT teachers today, in spite of several criticisms of it. That is to say, "no alternative better than the Grammar-translation method was available to teachers, and it also has some valuable points we should learn from even today." (Byram, 2017:251). As for the direct method, which are attractive to those who need real communication in the target language (instead of learning a language only to pass an exam), it is still criticized for not working well with large classes and less motivating students.

Every method has their own value in particular conditions, they also have limitations that need to be improved and updated by other methods. It is hard to say which is best, since in some particular contexts, each method is response to suitable results. These methods, however, cannot cater for all kinds of teaching contents and conditions. At the same time, they should combine some points from the other different 
methods.

\section{How to Implement Teaching Methodologies in Different Circumstance}

\subsection{Depending on Teachers' Beliefs}

One scholar has commented that "teachers' beliefs, attitudes and educational philosophies influence their teaching approaches" (Thomas, 2013). How teachers conceptualize their work and how they respond to their students depends on teachers' understanding of methodological principles and pedagogical content knowledge in different ways. For instance, when I worked as a high-school English language teacher, my teaching belief was to ensure that most of my students could pass the university entrance exam. Therefore, I used a lot of grammar-translation methods to help students memorize complicated grammatical rules and largely decontextualized vocabulary in my past teaching. In my view, it is a basic and useful way to build a correct English system for them. Furthermore, students' roles were to follow my instruction all the time and the classroom was entirely teacher-centered (Chandrika \& Susanne, 2018). As for pedagogical content knowledge, "professionally qualified teachers should be able to help students to take a deep approach to the acquisition of knowledge" (Nayak \& Rao, 2002), which always stimulates me to improve my professional knowledge and skills in my identity formation. Thus, my teaching belief based on my practical knowledge of pedagogical methods and professional knowledge of specific subjects has affected my teaching mode heavily.

However, the ever-growing need for good communication skills in English has created a huge demand for English teaching around the world (Richards, 2007). I want to achieve better and higher teaching objectives in my career. As pointed out by Chandrika and Susanne (2018), "there is an increasing demand for oral competence over the purely grammatical competence that was characteristic of the grammar-translation method". Then, I gradually realized that teachers today should emphasize the importance of communicative competence and regard students as the focus of learning process to some extent. Beyond that, I started to add a new teaching methodcommunicative language teaching method - in my classroom. For example, I set some pair works for students, so that they have opportunities to use English to interact with each other. In this case, I serve as a facilitator who establishes situations that can promote communication, rather than just a controller in the whole class. As for me, it is partly a movement from teacher-centered teaching approach to student-centered teaching approach. Besides, teaching focus also has been changed from grammatical rules to real communicative competence, as my teaching beliefs have improved.

\subsection{Depending on Teaching Contexts}

Teaching practice may take place in one or several different contexts. For example, you might be teaching in a campus-based ESL program, a local public school, a community college, or a private language institute (Richards
\& Farrell, 2011). In different contexts, the aim of teaching, the participants, the teaching content and the teaching method may always change according to subjective understanding of particular circumstance by individuals. There is no method that can apply to all kinds of teaching circumstance, and teachers are responsible for choosing the best methodology. In my experience, when I was teaching in a public high school in mainland China, the main content in my class was to explain the difficult words of literal meaning and grammatical structures of sentences for translating a passage from the target language into Chinese. I need to help senior students to master grammatical rules and pass the exam which consists of multiple choices and cloze tests. At that time, grammar-translation method may be the most suitable method for me to achieve teaching objectives. In China, most of teachers in public high schools have to strictly use grammar-translation method offered by national bureau of education. Under the Chinese Examination-oriented education system, this kind of method can be consistent with the expectations of students.

Now, I want to be an IELTS Speaking teacher in an international educational institution after graduation. The teaching content and teaching methods I will use may be different from what I taught in high school before. Campus-based teaching experiences (e.g., in a standard high school classroom) may be quite different to off-campus-based teaching experiences (Richards \& Farrell, 2011). The teaching contexts may be free and pluralistic, as it is funded by the personal entrepreneur who aims to create excellent environment for students to acquire real language skills. As an oral English teacher, I need to enable students to know how to use language for multiple different purposes and functions in real life. This requires lots of interaction and pair works. CLT will be used to help students perform functions: requesting information, accepting an invitation, completing transactions in a shop, restaurant and so on. Under this teaching context, I need to help students communicate through spoken English. If I just use grammar-translation method in the speaking class, I cannot reach the teaching goal of this class. Teaching contexts shape the methods of ELT used by the teacher. Hence, I use different methods in teaching high school English and IELTS Speaking. How I use some points from both these two methods for better teaching effects will be mentioned below.

\section{The Combination of Methods}

The following combination of methods cannot be regarded as the 'best', but it is a good way to combine good points from different teaching methods. In my opinion, IELTS speaking test is scored with respect to four different criteria, including Fluency \& Coherence, Grammatical Range \& Accuracy, Lexical Resource and Pronunciation, which I cannot just use one method to improve my students' competence to gain a qualified score for the application of overseas prestige universities. To reach better teaching objectives, I will integrate useful elements from task-based language teaching method, direct method and communicative language teaching method. For example, when I taught a speaking topic of part 2 - advertisements, the students were told that they were going 
to talk about a specific topic. Meanwhile, they were given some of the related English phrases for vocabulary building. I suppose that if they memorize and accumulate these phrases related to topic, it will be helpful when they talk about the advertisements to a high vocabulary level. Moreover, I will use English to make a demonstration for them. In this way, they can develop good pronunciation by following me. CLT will still be used to help students exercise speaking through pair works. At last, students' grammatical errors will be tolerated during fluency-focused practice, and these errors may be corrected during a later accuracy-focused activity. Thus, TBL is used by setting a real conversation context for them, DTM is adopted by using target language to give a demonstration and CLT is always applied in the whole class through interacting with students. In consideration of different ages and various levels of students in the private institution, I may have to alter and modify the styles of teaching method.

\section{Conclusion}

In summary, I agree with the statement from Hall (2011) that finding the best method of teaching foreign language is fruitless. The main reason lies in that every English teaching method has its advantages and limitations, and they will change and develop one by one over time. As claimed by Adamson, 'promoted methods are mirrors of the contemporary socio-cultural climate' (Adamson, 2004:615). The value of each method must have some contributions for particular learners and teaching contexts.

Teachers' beliefs and teaching contexts determine their teaching method, since contexts always change. Teachers should teach according to their own understanding of contexts and their own experience in their career. It is impossible to always use one good method in all kinds of circumstance. Thus, there is no 'best' method for teaching foreign language.

As far as I am concerned, the combination of different methods can benefit class a lot. If we use good points from specific teaching method and put them together to cover the shortage of dogmatic and single method, the class will be more productive.

\section{References}

[1] Adamson, B. (2004). fashions in language teaching methodology in A. Davies and C. Elder (eds): The handbook of applied linguistics. London: Blackwell, pp. 604-22.

[2] Richards, J., \& Farrell, T. (2011). Understanding the teaching context in practice teaching: A reflective approach (practice teaching, pp. 31-42). Cambridge: Cambridge University Press.

[3] Thomas, M. (2013). Teachers' beliefs about classroom teaching - Teachers' knowledge and teaching approaches. Procedia - Social and Behavioral Sciences, 89, 31-39.

[4] Cook, G. (2003). Applied linguistics. Oxford: OUP.

[5] Crookes, G. (2009). Values, philosophies, and beliefs in TESOL: Making a statement. Cambridge: CUP.
[6] Benati, A. (2018). Grammar-translation method. In Liontas, J. I., \& DelliCarpini, M. (Eds.). (2018). The TESOL encyclopedia of English language teaching. Hoboken, NJ: Wiley-Blackwell.

[7] Chandrika, B., \& Susanne, S. (2018). Teacher-fronted classes. In Liontas, J. I., \& Delli Carpini, M. (Eds.). (2018). The TESOL encyclopedia of English language teaching. Hoboken, NJ: Wiley-Blackwell.

[8] Byram, M., \& Hu, A. (2017). Routledge encyclopedia of language teaching and learning. London: Routledge, Taylor \& Francis Group.

[9] Darling-Hammond, L. (2000). How teacher education matters. In Journal of teacher education. 51 (3), 166-173.

[10] Hall, G., \& Hall, G. (2018). Language teaching methods: perspectives and possibilities. In Exploring English language teaching: Language in action. Abingdon, Oxon: Routledge.

[11] Richards, J. C., \& Lin, L. (2007). Communicative language teaching today. Beijing Shi: Ren Min Jiao Yu Chu Ban She.

[12] Jacobs, G. and Farrell, T. (2003). Understanding and implementing the CLT (communicative language teaching) paradigm. RELC Journal, 34/1: 5-30.

[13] Uztosum, M. S. (2013). An interpretive study into elementary school English teachers' beliefs and practices in Turkey. Turkish Online Journal of Qualitative Inquiry. 4(1), 20-33.

[14] Nayak, A. K., \& Rao, V. K. (2002). Classroom teaching: Methods and practices. New Delhi: APH Publishing Corporation.

[15] Pennycook, A. (1989). The concept of method, interested knowledge, and the Politics of language teaching. TESOL Quarterly, 23/4. 589-618. 